\title{
ДОЦІЛЬНІСТЬ ВВЕДЕННЯ НОВІТНЬОГО НАУКОВОГО НАПРЯМУ «УКРАЇНСЬКА АРХІТЕКТУРА / МІСТОБУДУВАННЯ / ЗНАВСТВО»
}

\author{
Ксеневич Михайло Якович \\ Українська академія архітектури \\ кандидат архітектурних наук, Україна
}

DOI: https://doi.org/10.31435/rsglobal_ws/30062019/6559

\section{ARTICLE INFO}

Received: 22 April 2019

Accepted: 17 June 2019

Published: 30 June 2019

\section{KEYWORDS}

Ukrainian architecture, urban development, architecture science, scientific direction, design.

\begin{abstract}
The article is devoted to the substantiation of the introduction of the scientific direction "Ukrainian architecture / urban planning / knowledge". Based on the reasoned grounds for the formation of a new scientific direction, the substantiated proof of its historical background and the analysis of the components and con-tent of the Ukrainian urban architecture, the feasibility of introducing a new scientific direction "Ukrainian architecture / urban planning / knowledge".
\end{abstract}

Citation: Ksenevich Mikhail Yakovlevich. (2019) Access to New Scientific Directions "Ukrainian Architecture / City-Building / Knowledge". World Science. 6(46), Vol.1. doi: 10.31435/rsglobal_ws/30062019/6559

Copyright: (C) 2019 Ksenevich Mikhail Yakovlevich. This is an open-access article distributed under the terms of the Creative Commons Attribution License (CC BY). The use, distribution or reproduction in other forums is permitted, provided the original author(s) or licensor are credited and that the original publication in this journal is cited, in accordance with accepted academic practice. No use, distribution or reproduction is permitted which does not comply with these terms.

Постановка проблеми. Становлення і розвиток української архітектури містобудування вимагає окремого виділення їі в науковий напрямок, який повинен включати кращі методичні та наукові підходи минулого і сучасності. Попри спадок минулого: планування і забудова масовою, типовою та денаціоналізованою архітектурою містобудування та їх утворень, по суті, ігноруються природні, етно-культурні витоки українського народу [1,2]. 3 настанням суттєвих політичних змін нині в Україні, а також враховуючи третю хвилю цивілізації у XXI столітті, - хвилю гуманізації, етнізації та уособлення, - посилюються тенденції до задресованості, ідентифікованості, автентифікованості архітектури життєвого середовища [5].

У зв'язку з цим доцільним є провести систематизацію та узагальнення множини фактів, виявлення новітніх тенденцій і закономірностей архітектурної містобудівної творчості в Україні.

Аналіз останніх досліджень і публікацій. Важливим теоретичним підгрунтям даного дослідження є праці К. Танге, Ж. Канділіс, Ле Корбюзьє, Л. Кан, А. Аалто, видатних архітекторів В. Кричевського, С. Сердюка, О. Сластіона, I. Левинського, О. Лушпинський, К. Жукова, C. Тимошенка, Д. Дяченка, В. Троценка, О. Вербицького, які 3 узагальнюючих позицій вибудовують національну особливість архітектури містобудування [3]. Проте дослідники та практики не розглядають цілісного поняття в контексті розвитку української архітектури.

Зважаючи на сучасне становлення і розвиток української держави, винятково важливе наукове та практичне значення, має розробка та конституювання окремого наукового напряму «Українська архітектура/містобудування/знавство». Тому $є$ потреба врахувати українські природні, людські і культурні контексти становлення та розвитку української архітектури містобудування в умовах новітньої, самостійної і незалежної України.

Враховуючи визнаність, наукову напрацьованість сучасного українознавства, що об'єднує українське природознавство, народознавство, культурознавство, а також українські мистецтвознавство, літературознавство, музикознавство та ін. Вагомим кроком до становлення 
i розвитку українського архітектуро/містобудування/знавства були напрацювання початку й кінця XX ст. та початку XXI ст. Українською академією архітектури, зокрема наукового документу «Національна програма розвитку архітектурної сфери в Україні». 3 огляду на наявне значне напрацювання за цією темою пропонується констатуювати пропонуємий науковий напрямок «Українська архітектура/містобудування/знавство».

Метою статті $€$ обгрунтування доцільності введення новітнього наукового напряму «Українська архітектура/містобудування/знавство».

Викладення основного матеріалу. Пізнання новітнього наукового напряму базуються на дослідженнях багатьох науковців-фахівців України та світу, з піднятого питання. Передусім вказане стосується ключових понять, таких як: «Україна», «українство», «українознавство», що являються основою визначення базових поняття наукового напряму «Українська архітектура/містобудування/знавство» (рис.1).

Передусім вказане стосується суб'єктів, об’єктів і предметів пізнання української архітектури/містобудування/знавства і робиться акцент на контекстуальності природної, людської і культурної складових явища-поняття, що пізнається. Спираючись на наукову опрацьованість спорідненості раніше розкритих, визначених та явищ-понять «українська архітектура містобудування» у всій іiі різноманітті проявів і реалій, у контексті понять «Україна», «українство» та «українознавство».

«Українська архітектура/містобудування/знавство», як $\mathrm{i}$ його родове поняття «українознавство» [1], є однією із складових пізнання та творення феномену українства й України, здійснених на історичному шляху, в процесі самопізнання, самореалізації, самоствердження, втілених у базових проявах ментальності, духовності та фізичної вдачі українства, та вирізняє його серед інших народів світу. Це органічно потребує переростання в українолюбство, українотворення, захист та відродження України і всього українського, зокрема й щодо української архітектури містобудування. На основі наукової джерельної бази щодо всебічного, комплексного, системного i контекстуального вивчення й висвітлення генези української архітектури містобудування, в контексті природи, людності, культури України як наукового напряму, що забезпечує адресність, ідентичність й автентичність складової українознавства як вищої родової системи. Суб'єкт, об'єкт і предмет пізнання архітектури/містобудування/знавства; мети і завдань, складових - розділів пізнання вказаного, що розкрито у відповідному дослідженні. Методичні основи дослідження вказаного базуються як на загальнонаукових, так і на конкретних та локальних методах архітектури/містобудування/знавства, передусім на: аналізі й синтезі; комплексності, системності i контекстуальності тощо. Фундаментом наукового напряму «Українська архітектура/містобудування/знавство», як і «українознавства» в цілому, є цілісна, поєднана i функціонуюча система знань 3 природознавства, народознавства і культурознавства й інших наук.

«Українська архітектура/містобудування/знавство», як і «українознавство» в цілому, включає суб'єкт, об'єкт і предмет пізнання. Де:

• суб'єкт пізнання - український народ та різні його угрупування громад творців, споживачів, управлінців та інших, задіяних в архітектурі містобудування та споріднених видах діяльності в Україні та за ії межами;

• об’єкт пізнання - українська архітектура містобудування та інші складові об'єкта пізнання;

- предмет пізнання - творення, існування, розвиток у минулому, сучасному i прогнозованому майбутньому української архітектури містобудування.

3 врахуванням контекстів: природознавства, народознавства та культурознавства й інше, як елементи цілісності наукового напряму, коренів, проявів і сутності становлення i розвитку української архітектури містобудування [4]. Такий підхід відповідає сучасним вимогам новітнього й актуального наукового напряму, в межах якого є місце для мон іторингу змін нині і у прогнозованому майбутньому «Українська архітектура/містобудування/знавство» на базі розвитку української архітектури містобудування. За прийнятою методикою (П. Кононенка) [1,3], відповідно до базових родових явищ «Україна», «українство», «український народ (етнос, нація)», є логічне підгрунтя та пропозицій розгортання наукового напряму пізнання і розкриття змісту й сутності явища «українська архітектура містобудування», що здійснюється через взаємопов'язане еволюційне і синхронне (одночасне і паралельне). А також діахронне (послідовне й історичне) дослідження відповідних концентрів населення, його угрупувань і поєднань. Все те у визначальних контекстах, таких як українські народ, природа, 
культура, що забезпечують й охоплюють пізнання та творення української архітектури містобудування.

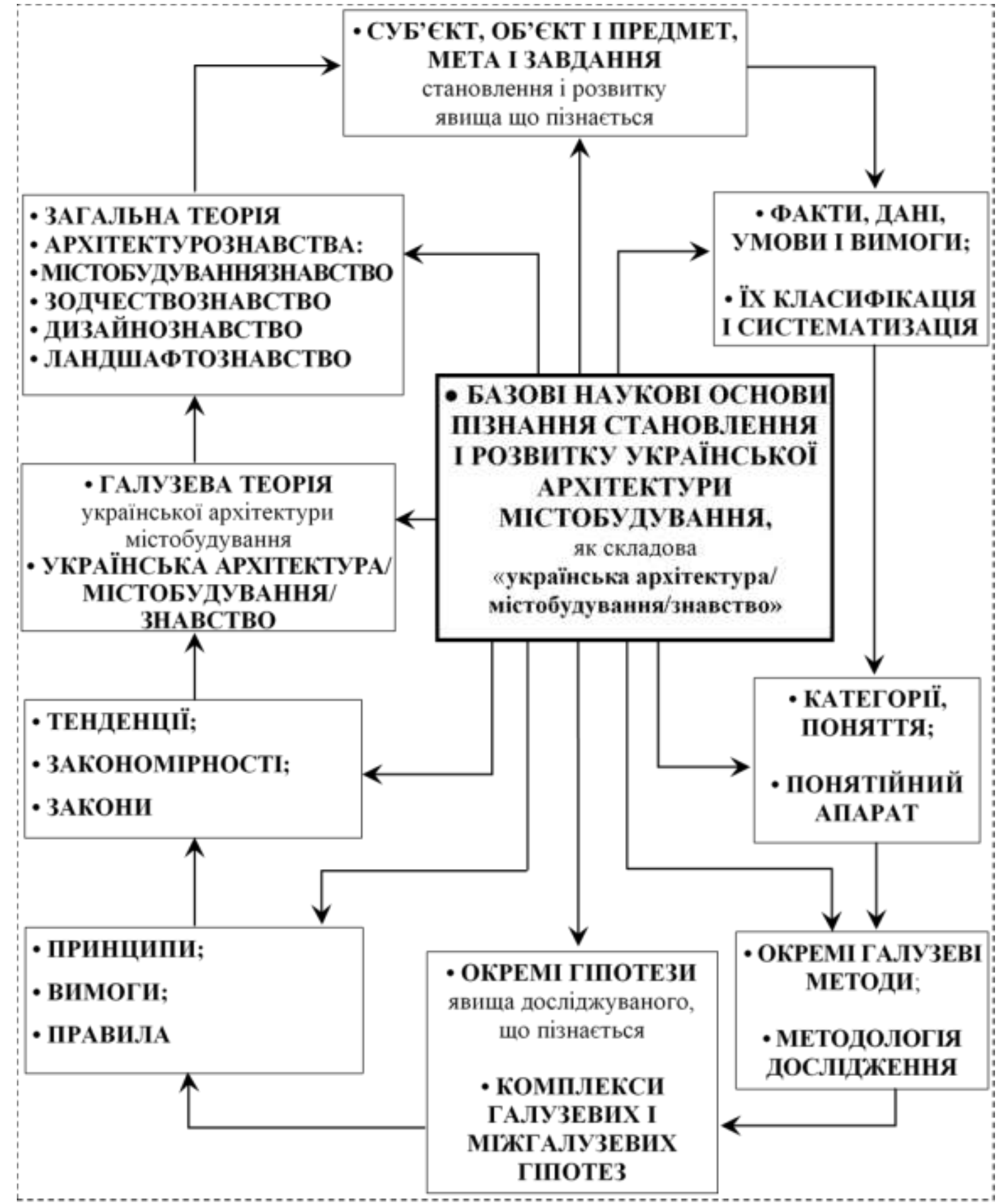

Рис. 1. Базові наукові основи пізнання становлення і розвитку украйнської архітектури містобудування

Тобто «Українська архітектура/містобудування/знавство», як $\mathrm{i}$ споріднене «українознавство», «постає як цілісна система самопізнання, виховання й навчання, єдності знання, любові i творення», як текстуально і контекстуально взаємопов'язана системна цілісність, єдність й існування (рис.2)

Що створює життєве середовище, його архітектуру, побут, господарювання та інші споріднені явища, їх спільні взаємозв'язки, взаємообумовленість та специфіку. 


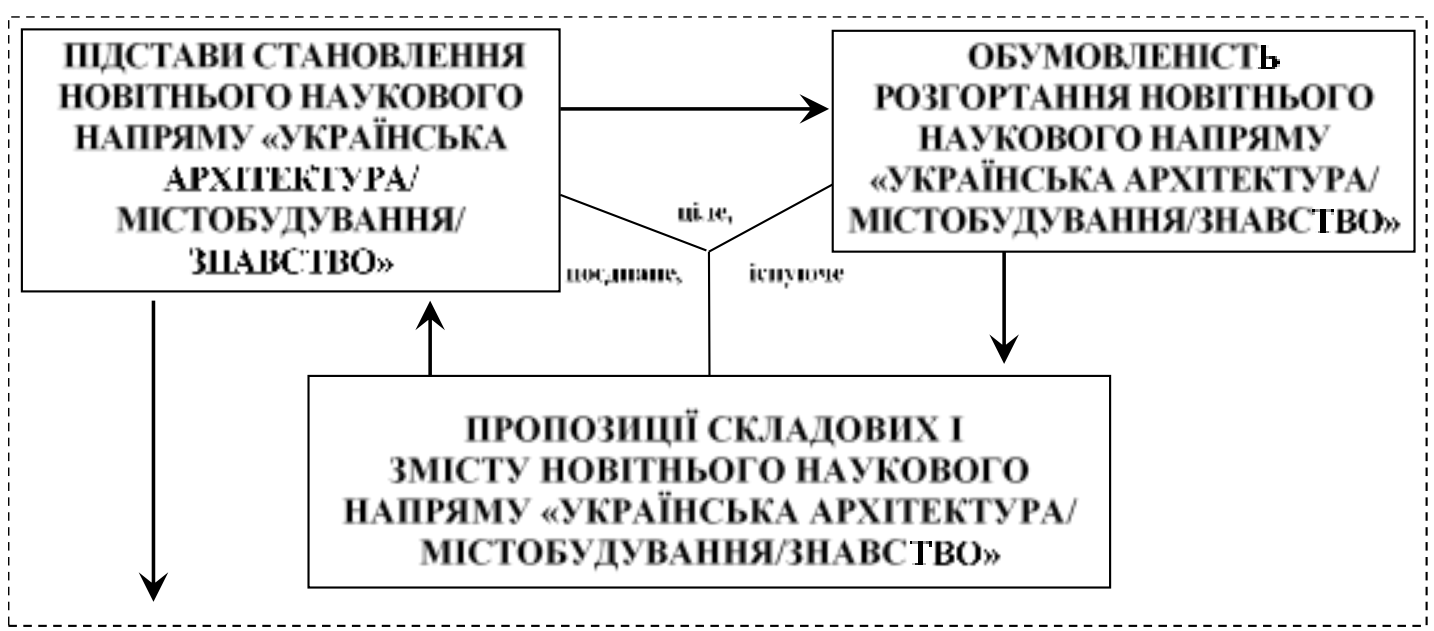

Рис.2. Структура становлення наукового напряму «украӥнська архітектура/ містобудування/знавство»

Вказане досліджувалося М. Грушевським, В. Вернадським, А. Кримським, С. Єфремовим, Д. Багалієм, I. Огієнком та іншими українськими вченими. Відзначимо також дослідників українознавства, що видали важливі для розуміння українознавства та української архітектура/містобудування/знавство праці енциклопедичного типу. Зокрема: 1916 р. • група авторів, очолюваних Ф. Вовком, М. Грушевським; 1931-35 рр. • колектив під керівництвом І. Раковського; 1949 р. • енциклопедисти під керівництвом В. Кубійовича й • нині праці П. Кононенка та ін.[4]. Разом 3 тим, відзначені здобутки в 30-і роки й у середині XX ст., були піддані ідеолого-політичній критиці як начебто націоналістичні, тож, відповідно, згорнугі та обмежені за сферою дослідження або й заборонені. Наслідок цих процесів сьогодні фатально-кризовий, тому потребує наукових напрацювань щодо галузей «Українознавство», «Українська архітектура/містобудування/знавство» тощо.

Аналізуючи факти, що збереглися, є підстави стверджувати: «Стає очевидним: поперше, що українство (не лише етнос, а й його мова, культура) - це явище загальнопланетарне; по-друге - поділ на українців і людей українського походження зумовлений їх долею i готовністю ідентифікуватися як українці; по-третє - все зазначене ставить десятки питань, на які можна відповісти лише за умови розуміння їх взаємопов'язаності та комплексності вивчення і висвітлення» (за П. Кононенком, на базі досліджень М. Грушевського, Ю. Липи, В. Вернадського, О. Братка-Кутинського, а також М. Сергійчука, В. Шендеровського та ін.). Отже, прояв украськості в архітектурі містобудуванні України, як і в інших сферах, потребує усвідомленого сприйняття, розуміння і розвитку, від загальносвітовогознавства до конкретно українознавства й українська архітектура/містобудування/знавства. На всіх етапах і рівнях становлення і розвитку вказаного наукового напряму, мають виконуватися різноманітні дослідження, починаючи від простіших (дослідження-розповіді про українську народну й професійну архітектуру життєвого середовища, про певну взаємодію української архітектури містобудування з українським побутом, звичаями, мораллю, естетичними нормами тощо) через складніші комплексні дослідження української родини, громади, етносу; виробництва, економіки, права тощо, до синтезуючих системних і контекстуальних пізнання і творення пов'язаних складових цілого сьогодення та прогнозованого майбутнього України.

Сукупність наявних наукових досліджень нині охоплюються багатьма різними сферами, галузями та інституціями складових фундаментальних та прикладних наук, що утворюють русло єдиного наукового напряму «українознавство», де вагомою складовою $\epsilon$ «українське архітектуро/містобудування/знавство», як складова цілого. Встановлено, що науковознавча сфера «українське архітектурознавство» розподілено за галузево-рівневими ознаками: архітектура містобудування i систем розселення; архітектура будівель і споруд; дизайн архітектурного середовища. Наступний розподіл класифікований за ознаками додатковості й граничності розподілення сфер є досліджуємий напрям теорії та практики, що охоплюють відповідно біоніку, кваліметрію, історію, будівельну фізику, будівельні матеріали і конструкції та інше, які розкривають українську специфіку явища, що пізнається і твориться. Вищевказані напрями і розділи досліджень української архітектури містобудування потребують взаємоузгодження та поєднання розпорошених 
складових практики і теорії в єдиний задресований і актуалізований науковий напрям - «Українське архітектурознавство життєвого середовища», із складовою «Архітектура/містобудування/знавство».

Сьогодні основні напрями спеціальностей і профілів професійної підготовки та діяльності в сфері науки, освіти та практики української архітектури життєвого середовища, що історично склалися, потребують доповнення зокрема поняттями: адресність, ідентичність й автентичність явище, що пізнається, потребує поєднання сутності, форми і прояви українського народу (рис.3). За цими напрямами і спеціальностями необхідно нині й конкретизувати навчання, захист наукових дисертацій, випуск наукових збірників, розроблення державних, регіональних і місцевих норм та правил тощо $[3,4]$. Що, у свою чергу, мають відповідати потребам становлення і розвитку новітньої самостійної і незалежної України. На цьому тлі існує необхідність розробки новітнього напряму «Українська архітектура/ містобудування/ знавство» з визначенням специфіки суб'єкта, об'єкта і предмета пізнання й втілення, цілей, завдань і обмежень й результатів. Вказане потребує подальших адресних, ідентифікованих та автентизованих напрацювань та експериментальних апробацій.
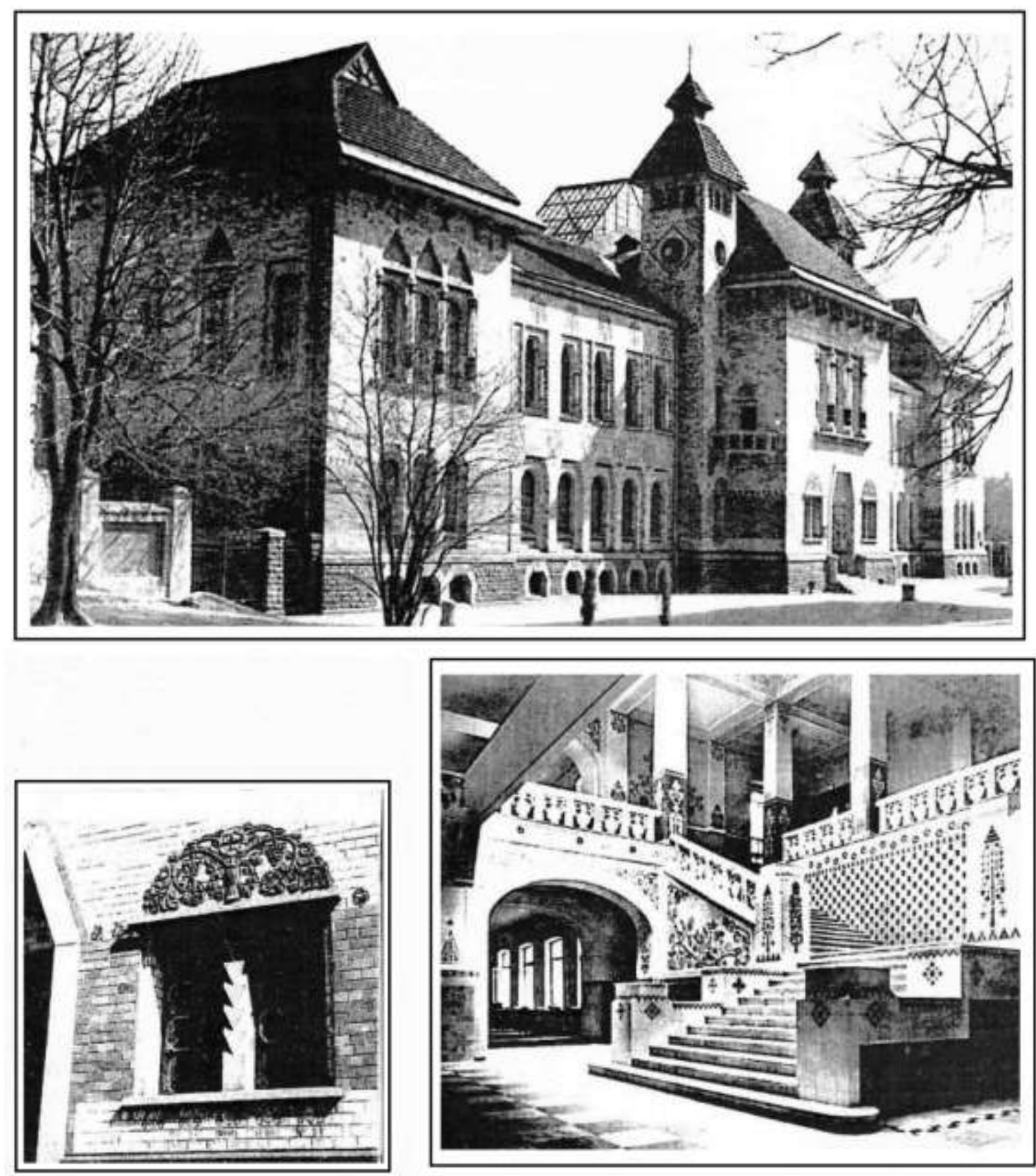

Рис. 3. Приклад прояву адресності, ідентичності і аутентичності украӥнської архітектури громадського об'єкта ХХ ст. Архітектор В. Кричевський, м. Полтава, Будинок губернського земства. 
Висновки. Узагальнюючи розкрите вище, та виходячи з рівнів становлення і розвитку різних сфер сучасного наукознавства пропонується диференціювати розподіл історичноусталених наукових накопичень щодо архітектури життєвого середовища. А саме, що охоплює рівні: - загальні основи теорії української архітектури життєвого середовища включно й загальна українська архітектура/містобудування/знавства, як фундаментальний рівень, а також: - основи конкретних, згрупованих та окремих локальних складових «Української архітектури/містобудування/знавства» - прикладні рівні. Слід також розширити й поглибити опрацювання окремих аспектів досліджуємого явища, що $є$ актуальним і інноваційним нині й на перспективу, в розумінні специфіки різноманітних потреб професійної діяльності у сферах теорії і практики української архітектури життєвого середовища. Зокрема семантики, композиції, тектоніки, стилістики тощо.

Поглиблення та розширення знань, становлення і розвитку української архітектури містобудування, відповідно й «Українська архітектура/містобудування/знавство», що потребує законодавчої та науково-методичної конституалізації як новітнього наукового напряму, а також подальшої певної актуалізації та узгодженості існуючих і новітніх знань, прогнозованих станів, що витримали випробування часом. Розроблені наукові основи становлення і розвитку української архітектури містобудування на сучасному етапі розвиту України, в контексті іiі природи, народу і культури - $є$ важливими й актуальними для подальшого розгортання теорії і практики сфер архітектури життєвого середовища, іiі задресованості, ідентифікованості та автентизованості подальшого становлення і розвитку українського народу. Отже й становлення і розвиток відповідного наукового напряму «Українська архітектура/містобудуван-ня/знавство» всіх рівнів та горизонтів та впровадження опрацьованого до подальшого становлення i розвитку в Україні.

\section{ЛIТЕРАТУРА}

1. Кононенко П. П. Українознавство: Навч. посібник. - К.: Заповіт, 1994. - 320 с.

2. Ксеневич М. Я. Українська архітектура, іiі визначальний контекст у просторі, часі, інформації. Основи українського архітектурознавства. - К.: Українська академія архітектури, Київський національний університет будівництва і архітектури, «МП Леся», 2005. - 426 с.

3. Соченко В. І. Українська архітектура: традиції, новації сучасність // Збірник «Сучасні проблеми і містобудування». - К.: 2000. - С.174-186.

4. Тімохін В. О. Основи містобудування / Навч. посібник. - К.: ІЗМН, 1996. - 216 с.

5. Українці: Історико-етнографічна монографія у двох книгах. / За наук. ред. докт. істор. наук А. Пономарьова. - Опішне: Українське народознавство, 1999. Книга 1. - 528 с., Книга 2. - 544 с. 